Article

\title{
Culturally Responsive Teaching: Implications for Educational Justice
}

\author{
Magnus O. Bassey \\ Queens College, The City University of New York, 65-30 Kissena Blvd., Queens, NY 11367, USA; \\ magnus.bassey@qc.cuny.edu; Tel.: +1-718-997-5335 \\ Academic Editor: Judith Könemann \\ Received: 14 June 2016; Accepted: 25 October 2016; Published: 2 November 2016
}

\begin{abstract}
Educational justice is a major global challenge. In most underdeveloped countries, many students do not have access to education and in most advanced democracies, school attainment and success are still, to a large extent, dependent on a student's social background. However, it has often been argued that social justice is an essential part of teachers' work in a democracy. This article raises an important overriding question: how can we realize the goal of educational justice in the field of teaching? In this essay, I examine culturally responsive teaching as an educational practice and conclude that it is possible to realize educational justice in the field of teaching because in its true implementation, culturally responsive teaching conceptualizes the connection between education and social justice and creates the space needed for discussing social change in society.
\end{abstract}

Keywords: social justice; culture; education

\section{Introduction}

In her recent book, Geneva Gay defines culturally responsive teaching as "using the cultural knowledge, prior experiences, frames of reference, and performance styles of ethnically diverse students to make learning encounters more relevant to and effective for [students]" [1] (p. 31). Gloria Ladson-Billings maintains that culturally responsive teaching is "a pedagogy that empowers students intellectually, socially, emotionally, and politically [because it uses] cultural referents to impart knowledge, skills, and attitudes" [2] (p. 20). Teachers who use a culturally responsive method in their teaching see culture as a strength which can be used effectively to enhance academic and social achievement [2]. According to scholars who have studied this method of teaching, culturally responsive teachers are grounded in pedagogical practices, teaching conceptions, and social relationships that enhance social justice because these teachers relate the curriculum to students' backgrounds, establish connections with families, understand students' cultural experiences, establish connections with local communities, create shared learning experiences, and recognize cultural differences as strengths on which to build programs [1-10]. Teachers who practice culturally responsive teaching understand that education is not apolitical and, as a result, they help students to understand their roles as change agents in society. These teachers inspire, motivate, instill values and knowledge; they nourish racial pride and the need for equality [1,2,5-7,11]. In her exemplary book, Ladson-Billings [2] identifies eight teachers who she describes as successful teachers of African-American students. These teachers are successful because they utilize students' culture as a vehicle for learning; they have a strong focus on student learning; they are creative; they develop cultural competences and cultivate sociopolitical awareness in their students. Indeed, in this remarkable study, Ladson-Billings [2] tells us how one of the teachers used rap music as a vehicle for teaching poetry to African-American students enabling her students to outperform students from other schools who did not use such an approach; another teacher involved parents in her classroom by creating an "artist or craftsperson-in-residence" program that enabled parents to share their wisdom and knowledge with students by allowing students to learn from 
parents in the community. Parents were often invited to this teacher's classroom to share their cultural knowledge with students. In a different direction, a teacher encouraged her students to use their native languages in class while learning the standard language simultaneously, resulting in her students' remarkable ability to be fluent in both languages [2]. Similar studies of culturally responsive teaching by Gehlbach [12]; Johnson, Nyamekye, Chazan and Rosenthal [13]; Gay [1]; Delpit [6]; Lipman [7]; Maiga [8]; Shujaa [9] and Tate [10], recorded similar academic successes by students in different subject areas. The reason why teachers who practice culturally responsive teaching are successful is that they are enthusiastic about their work; they are respectful of parents, and they understand Black children's duality of operating in many worlds: that is, in the world of their home environment, in the world of the school community, and in the world of the global community. Other characteristics of empowering teachers are that they support culture as an integral part of the school experience, they have very few discipline problems in their classrooms and have very high attendance rates. As a result, students score at the highest percentile on standardized tests in their classes $[1,2,5,6]$. Because students in these classes experience academic success they develop critical competence and critical consciousness. Indeed, after a careful review of numerous educational studies, Gay [1] concluded that African-American students perform better in schools where teaching is filtered through their own experiences. To be effective, teachers of minority students must have the courage, confidence and competence to teach in a culturally responsive manner. Recent scholarships on empowering pedagogy for minority students include those by Bassey; Ladson-Billings; Gay; Johnson et al.; Gehlbach; Hammond; Delpit; Lipman; Maiga; Shujaa and Tate [1-10,12-14]. These studies underscore the importance of culturally responsive teaching because, as these researchers found out, culturally responsive teaching is good for all children. In culturally responsive classrooms all children are valued and their contributions recognized; teachers are responsive to the needs of all children; they care for all children; they begin with common ground but celebrate the unique contributions of every child; they use multiple teaching and learning strategies to engage students in active learning that encourages the development of critical thinking, problem solving and performance skills; and indeed, these teachers are able to adapt instruction to meet the needs of individual students [1-5,7-9,14,15]. Empowering teachers make good teaching choices by eliciting, motivating, engaging, supporting, and expanding the intellectual abilities of all students [14].

By using a culturally responsive method of teaching, civic citizenship and social justice can be achieved because culturally responsive teaching encourages students to be active participants in the fight for social change and social justice through social activism by volunteering, doing charity work, engaging in civic duties and civic values [2]. Chilcoat \& Ligon [16,17], Perlstein [18] and Levy [19] describe an example of such a curriculum for African-American students in Mississippi that was designed to make students to become a force for social change. The curriculum was initiated to empower students to critically examine their existing conditions so as to "gain knowledge and confidence to activate change, and to prepare themselves to contribute creatively and positively in their communities" [17] (p. 2). The students were "acquainted with different points of view; to stimulate, challenge, and expand ideas and opinions; to explore possibilities of community and social improvement through collective decision making; and, hopefully, to effect those possibilities" [17] (p. 3). In their classrooms, students were taught how to channel their frustrations appropriately to initiate change because culturally responsive teaching encourages students' involvement in social development projects through collective action as a way of effecting change in their own communities. Furthermore, by enhancing students' capacity for democratic participation, students become active and engaged citizens.

\section{Culturally Responsive Teaching as Social Justice Education}

An important overriding concern I raised in my introduction was: how can we realize the goal of educational justice in the field of teaching? While there is a great deal of contention about what social justice in education means, Jessica Heybach [20] provides three perspectives of social justice which I find interesting and relevant to this discussion. These are: social justice as a means 
of exposing and altering the institutions which perpetuate systematic oppression; social justice as a means of perceiving oppressive patterns that affect students as individuals and others in society; and social justice as a means of developing wide-awakeness [20] (p. 239). Gloria Ladson-Billings [5], one of the leading scholars in culturally responsive teaching maintains that, "[b]eyond ... individual characteristics of academic achievement and cultural competence, students must develop a broader sociopolitical consciousness that allows them to critique the cultural norms, values, mores, and institutions that produce and maintain social inequalities" [5] (p. 162). In a number of articles, Chilcoat and Ligon [16,17], Perlstein [18], Ladson-Billings [5], Levy [19], describe innovative instructional programs in Freedom Schools for African-American students which allowed students to participate in community, critical thinking and political activities using progressive democratic instructional methods. The methods used in these schools included discussion in art, social action, creative writing, drama, newspaper commentaries, social action projects and role playing in class. Students were allowed to examine public policies critically so that they could participate in civic transformations effectively. They explored forms of systemic oppression, inequality and social hierarchy. The curriculum set for itself the task of uncovering how power is used to either frame or distort processes or interactions and unraveled, unmasked and critiqued domination and discrimination [5,16-19]. Students were required to confront, contradict, and contest inequality and unequal power relations particularly when differences were used to justify systemic inequalities in society.

Culturally responsive teaching is informed by the principles and practices of freedom, equality and social justice $[4,5]$. Its integrated focus is demonstrated by its involvement in concrete struggles for the freedom of all peoples. In her study, Ladson-Billings states that she went into the classrooms "to examine both the political and the practical" [2] (p. 15), and notes: "I wanted to see not only why a certain kind of teaching helped the students to be more successful academically but also how this kind of teaching supported and encouraged students to use their prior knowledge to make sense of the world and to work toward improving it" [2] (p. 15).

Indeed, what Gloria Ladson-Billings [2] envisioned and in some instances saw in some of the schools that she studied was a linkage between academic work and community engagement in the classrooms [2] (pp. 156-157). The exalting thing about the workings of these classes was that students were not only challenged to ask the 'why' questions, they were challenged to uncover the causes of injustice and to envision themselves as agents of change because culturally responsive teaching emphasizes social justice outcomes over and above mere citizenship objectives. It should be pointed out that social justice outcomes include not only patriotism to country but also "allegiance to universal human values, democratic ideals, and human rights and dignity of all people in the world" [21] (p. 10). Recognizing the importance of these intersections enables teachers to develop a teaching approach that emphasizes the importance of being able to relate to others and to empathize with their thoughts and feelings, which lends itself to the development of mutual respect.

Culturally responsive teaching focuses on social change and social justice and encourages students to engage in civic and social justice initiatives. It insists that students develop a commitment to service as well as to social justice ideals. It starts from the premise that society is not perfect, therefore, it encourages students to uncover the root causes of such imperfections. By understanding society's imperfections, a student's consciousness is raised about issues of society's injustice. In culturally responsive classes, students are taught to balance classroom components with social responsibility as well as commitment to community change [2]. As a result, during the semester, students are engaged in their chosen social justice endeavors or in some form of community political activism which may include registering voters, participating in school board meetings, serving in soup kitchens, helping at homeless shelters, taking care of the poor etc. The consideration here is for students to acquire civic participation skills including, "organizing and conducting public meetings, preparing agendas, writing letters to newspapers and politicians, public speaking, conducting opinion polls, campaigning, utilizing leadership skills, and volunteering" [21] (p. 18). According to Mitchell [22], "The concepts and issues of identity, oppression, power, and privilege raised through dialogue in the (culturally 
responsive) classroom in tandem with the action of meaningful service in the local community and reflection on both offers the praxis that can lead to the perspective and action desired from students in developing commitments to social justice "[22] (p. 109).

Other rallying points in favor of culturally responsive teaching is that it cements the connection between social justice and pedagogy and creates the space needed for discussing social change in the classroom $[2,5,23]$. Rather than wallow in or blame their students' lack of resources for low performance, culturally responsive teachers do something to create a vibrant learning environment for their students. For example, a leading advocate tells us how he collaborated with his African-American fifth graders to acquire the learning resources that his students needed [24]. The teacher, Mr. Schultz, co-created a year-long authentic, transformative and integrated curriculum with African-American fifth graders in Chicago, Illinois to get a new school building for his students and their community. He wrote, "In their quest to replace their under-funded and marginalized school, the students were 'able to identify root causes of problems' and also ready and willing to implement 'strategies that might bring about substantive changes'" [24] (p. 166). Having identified the poor condition of their school building as the major problem confronting them, Mr. Schultz's fifth graders came up with strategies to act and effect change. Their most critical issue was their decaying school building. The students identified how they would make their problem known to the community by pinpointing people to talk to, making their plight known through publications in newspapers and magazines and button holding politicians. Those that the students targeted were law makers, members of the school board, school administrators and staff, political leaders and major corporations. Two newspapers were chosen by the class to help in the publicity. The students also discussed ways of putting pressure on members of the community to achieve their goals. Their approach included "surveying students, teachers, and staff; petitioning; interviewing people with power in the community; writing letters to the legislature and inviting politicians to the school; holding a press conference; and producing a documentary video" [24] (p. 169). Other approaches adopted by the students included composing letters to the media, writing to people who mattered in the community as well as writing letters to the political elites in the community. Within a very short period of time newspapers and the entire community picked up the students' story and people in the community started to demand answers. Academically, the students learned several skills in the process including cooperative work, how to conduct surveys, how to make documentations and how to take photographs. They also learned how to write, make assessments, analyze data and solve mathematics problems. He maintained that the students' hard work was healthily rewarded with a better school building in subsequent years and numerous public service awards [24]. He concluded:

[The students'] initiative and perseverance paid off. Although there was some disappointment and frustration in not getting an immediate response from the 'decision makers at the board of education and the city,' other people certainly responded, hearing the cries for equity in schooling. From local legislators visiting and lobbying on the students' behalf ..., to inquiries from university professors interested in writing about the project, to concerned citizens-including Ralph Nader-paying visits, the students were applauded and awarded for their fine work. [24] (p. 171)

Culturally responsive teachers view the cycle of social, educational and other injustices in society through the lens of political analysis of power and legitimation of meanings. The important argument here is that privilege, identity and disadvantage have been used to justify systemic inequalities in society through the dynamics of power. In its effort to contest inequality, culturally responsive teaching therefore instills in students a sense of self and political consciousness designed to empower them in transforming the political landscape as a way of ushering in a more equitable democracy [23]. This is to say, culturally responsive teaching rejects the view that schools are apolitical. On the contrary, it construes schooling as a form of cultural politics which influences not only the construction and production of meaning but how identities are formed and reproduced in society. Its overarching purpose then is to transform structural inequalities as it affects various groups in society. Therefore, 
culturally responsive teaching not only teaches students how differences have been used as tools for justifying inequalities but informs them how to transcend the boundaries of injustice and debilitating restrictions imposed by the wider society on some citizens [3,4]. As such, it provides not only awareness of, but the means for constructing countervailing platforms of struggle by teaching students how to interlock with civil society in order to change despair into hope and hope into optimism. In other words, culturally responsive teaching is critical of domination, discrimination, subjugation and dehumanization of individuals and groups. It calls for public policy to be informed by the spirit of equity, social justice and fairness to all $[3,4]$.

\section{Conclusions}

This article maintains that a truly transformative agenda of social justice can be achieved by using culturally responsive teaching in our classrooms because culturally responsive teaching activates civic citizenship of all students, keeps students awake, and makes them active participants in the fight for social change. Also, studies by numerous scholars $[1,2,5-10,12-14]$, show that students, particularly minority students, do better academically in schools where teachers use culturally responsive teaching than in schools where teachers do not use such a method.

Conflicts of Interest: The author declares no conflict of interest.

\section{References}

1. Gay, G. Culturally Responsive Teaching: Theory, Research, and Practice, 2nd ed.; Teachers College Press: New York, NY, USA, 2010.

2. Ladson-Billings, G. The Dreamkeepers: Successful Teachers of African American Children, 2nd ed.; Jossey-Bass: San Francisco, CA, USA, 2009.

3. Bassey, M.O. Education for civic citizenship and social justice: A critical social foundations approach. Educ. Chang. 2010, 14, 247-257. [CrossRef]

4. Bassey, M.O. The centrality of experience in Carter G. Woodson's The Mis-Education of the Negro. J. Philos. Hist. Educ. 2015, 65, 123-135.

5. Ladson-Billings, G. But that's just good teaching! The case for culturally relevant pedagogy. Theory Pract. 1995, 34, 159-165. [CrossRef]

6. Delpit, L. Other People's Children: Cultural Conflict in the Classroom; The New Press: New York, NY, USA, 1995.

7. Lipman, P. "Bringing out the best in them": The contribution of culturally relevant teachers to educational reform. Theory Pract. 1995, 34, 202-208. [CrossRef]

8. Maiga, H.O. Bridging classroom, curriculum, and community: The Gao school museum. Theory Pract. 1995, 34, 209-215. [CrossRef]

9. Shujaa, M.J. Cultural self meets cultural other in the African American experience: Teachers' responses to a curriculum content reform. Theory Pract. 1995, 34, 194-201. [CrossRef]

10. Tate, W.F. Returning to the root: A culturally relevant approach to mathematics pedagogy. Theory Pract. 1995, 34, 166-173. [CrossRef]

11. Fairclough, A. A Class of Their Own: Black Teachers in the Segregated South; The Belknap Press of Harvard University Press: Cambridge, MA, USA, 2007.

12. Gehlbach, H. Creating birds of similar feathers: Leveraging similarity to improve teacher-student relationships and academic achievement. In SEYS Educational Psychology Lecture Series; Department of Secondary Education and Youth Services, Queens College, The City University of New York: New York, NY, USA, 2014.

13. Johnson, W.; Nyamekye, F.; Chazan, D.; Rosenthal, B. Teaching with speeches: A Black teacher who uses the mathematics classroom to prepare students for life. Teach. Coll. Rec. 2013, 115, 1-26.

14. Hammond, Z. Culturally Responsive Teaching \& the Brain; Corwin: Thousand Oaks, CA, USA, 2015.

15. Athanases, S.Z.; Wahleithner, J.M.; Bennett, L.H. Learning to attend to culturally and linguistically diverse learners through teacher inquiry in teacher education. Teach. Coll. Rec. 2012, 114, 1-50.

16. Chilcoat, G.W.; Ligon, J.A. Developing democratic citizens: The Mississippi freedom schools as a model for social studies instruction. Theory Res. Soc. Educ. 1994, 22, 128-175. [CrossRef] 
17. Chilcoat, G.W.; Ligon, J.A. "Great potential curriculumers": Educational projects that informed the curriculum design of the Mississippi freedom schools. In Presentation at the American Educational Research Association Annual Meeting, Division B, Curriculum Studies, Session Number 33.63, New Orleans, LA, USA, 27 April 2000.

18. Perlstein, D. Teaching freedom: SNCC and the creation of Mississippi freedom schools. Hist. Educ. Q. 1990, 30, 297-324. [CrossRef]

19. Levy, M. A monumental dissent. In Finding Freedom: Memorializing the Voices of Freedom Summer; Johnson, J., Ed.; Miami University Press: Miami, OH, USA, 2013.

20. Heybach, J. Rescuing social justice in education: A critique of the NCATE controversy. Ohio Val. Philos. Educ. Soc. 2009, 40, 234-245.

21. Ahmad, I.; Szpara, M.Y. Education for democratic citizenship and peace: Proposal for a cosmopolitan model. Educ. Stud. 2005, 38, 8-23.

22. Mitchell, T.D. Critical service-learning as social justice education: A case study of the citizen scholars program. Equity Excell. Educ. 2007, 40, 101-112. [CrossRef]

23. Gay, G.; Kirkland, K. Developing cultural critical consciousness and self-reflection in preservice teacher education. Theory Pract. 2003, 42, 181-187. [CrossRef]

24. Schultz, B.D. Not satisfied with stupid band-aids: A portrait of a justice-oriented, democratic curriculum serving a disadvantaged neighborhood. Equity Excell. Educ. 2007, 40, 166-176. [CrossRef]

(C) 2016 by the author; licensee MDPI, Basel, Switzerland. This article is an open access article distributed under the terms and conditions of the Creative Commons Attribution (CC-BY) license (http://creativecommons.org/licenses/by/4.0/). 